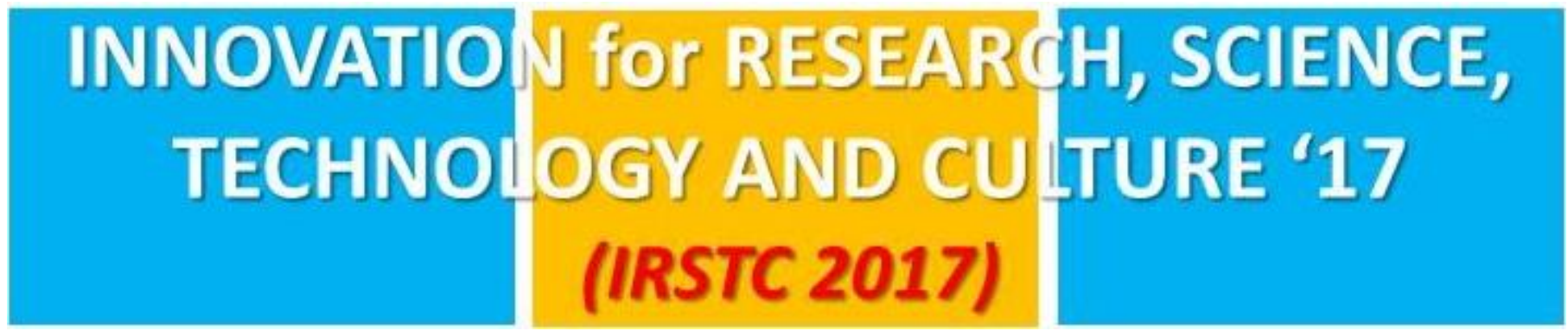

$4^{\text {th }}$ INTERNATIONAL SEMINAR: RESEARCH FOR SCIENCE, TECHNOLOGY AND CULTURE (IRSTC 2017)

\title{
Effect of Solar Cell for Quality Dryer Fertilizer Based on ANN Method
}

\author{
Solly Aryza ${ }^{1}$, Faisal Irsan Pasaribu², Muhammad Fadlan Siregar ${ }^{3}$, Muhammad Irwanto $^{4}$, Andysah \\ Putera Utama Siahaan ${ }^{5}$, Zulkarnain Lubis ${ }^{6}$
}

\footnotetext{
${ }^{1,5}$ Postgraduate Student of Universiti Malaysia Perlis, Pauh, Perlis, Malaysia ${ }^{1}$ Faculty of Engineering, Universitas Pembangunan Panca Budi, Medan, North Sumatera, Indonesia ${ }^{5}$ Faculty of Computer Science, Universitas Pembangunan Panca Budi, Medan, North Sumatera, Indonesia ${ }^{2}$ Faculty of Engineering, Universitas Muhammadiyah Sumatera Utara, Medan, North Sumatera, Indonesia

${ }^{3}$ Faculty of Engineering, Universitas Cut Nyak Dien, Medan, North Sumatera, Indonesia.

${ }^{4,6}$ Faculty of Engineering, Institut Teknologi Medan, Medan, North Sumatera, Indonesia.
}

\begin{abstract}
Study the characteristics of drying under drying temperature conditions between $60-80^{\circ} \mathrm{C}$, drying air velocity $0.6-1.4 \mathrm{~m} / \mathrm{s}$ and $6-10 \mathrm{mesh}$ particle size. This paper describes a design and realization of fertilizer dryers based on ANN Methode. In addition to the amount of production more, the cost of operation can also be minimized as much as possible and require less power, so the manufacturing process even higher profits. Automation is one of the realizations of technological development and is the only inevitable alternative to acquiring a simple, practical, and efficient work system to achieve results with a high degree of accuracy. The time aspect should also be considered, because with the shorter the time required for the production process, it will get better results and faster when compared with production processes that take longer. A measurement of the reduction of solid mass of the fertilizer in the tray as a function of time for various conditions of drying air temperature, wind velocity, and particle size. The drying characteristic is expressed in moisture content as a function of time and rate of drying as a function of free moisture. The experimental results show best of the drying rate is strongly influenced by the rise in drying air temperature and drying air velocity. The solar cell is one of the methods in the dryer power supply through the thermostat.
\end{abstract}

Key-word: - Fertilizer Dryer, ANN methode, Solar Panel.

\section{Introduction}

Fertilizer one of a requirement in the agricultural industry sector. Indonesia as a country that is still dependent on the agricultural sector, the fertilizer becomes the foundation for maintaining the resilience in the agricultural sector. Indonesia is one of the largest fertilizer producing countries in the world, especially in Asia. The production fertilizer of maximal crop quantity, with an efficiency of the restricted use of potentially hazardous materials such as fertilizers and pesticides. The quality of NPK fertilizer by water content in the fertilizer. The water content in NPK fertilizer in the market is limited to about $1.5 \%$. The drying process in the NPK fertilizer industry plays an important role where the water content in the fertilizer specification is restricted to a maximum of $1.5 \%$. The water content in the fertilizer determines the quality of the fertilizer because the basic nature of the fertilizer that easily absorbs moisture from the air (hygroscopic) in nature. Excessive water content can damage the granular structure of the fertilizer affecting the quality and nutrient content of the fertilizer (Ben-Shmuel etall. 2013). Drying is the reduction of the liquid content (natural water) of the solid by evaporation using a drying air medium (Zou Jifeng, 1999). The drying process is one of the processes in industries that require relatively high energy but usually operate with low thermal efficiency. The drying process on an industrial scale requires the proper and efficient design of dryers. The design of these dryers requires data on the drying characteristics of the solid material. Therefore, a study of the drying characteristics of NPK fertilizer (15:15:15) using Tray Dryer is needed because research on the drying characteristics of NPK fertilizer (15:15:15) using Tray 
Dryer is still very low. This study aims to find a suitable model to explain the drying characteristics of NPK fertilizer using semiempirical drying model which has been widely used in agricultural products as well as to examine the effect of drying air temperature, dryer air velocity, sample size and moisture content on fertilizer drying characteristics NPK.

So with the development of technology so that the situation can be done with the implementation of technology, Automation is one of the realization of technological advances and is the only alternative that can not be avoided again to obtain a simple, practical, and efficient work system so as to get results with the level high accuracy. The timing should also be considered because with the shorter time required for the production process; it will get better results and faster when compared with production processes that take longer time added by using sunlight as an energy source for fertilizer dryers that can be portable.

In addition to the amount of production more, the cost of operation can also be minimized as much as possible and require less power, so the manufacturing process even higher profits. Also, a new approach to the optimization problem is with the integration method of an Artificial Neural Network (ANN) with Bidirectional Improved Particle Swarm Optimization. Currently, this algorithm is used to improve the optimization of the manufacturing of roof cement. In determining the quality of cement, steel pressing process is carried out. The problem is that it 's hard to determine the quality of the resulting roof cement. Because of these problems, the manufacturer then has to revert to the traditional approach that is based on skills and human judgment, but this method raises issues of work delays, waste, and error assurance that the decision is taken to determine whether or not the pressure of steel is optimal.

This study implements the integration of ANN in determining the required dose in providing a combination of fertilizers. ANN is used to determine the influence exerted by various combinations of fertilizers. Afterward, the dryer machine will optimize the dose of fertilizer, by the primary influence needed by farmers also this machine will be portable suppose used solar cell

\section{Method}

This research was carried out on a scale small drying machine. The temperature of the dryer air is measured using a thermocouple which is connected withdigital displays. The dryers are also equipped with digital scales to measure changes in solid mass during the drying process. Where this research using NPK fertilizer type 15:15:15 from PT. Petrokimia, Gresik, East Java. The aim step of the research was to prepare the NPK fertilizer material, i.e., the reduction of particle size by the process of collision and screening into three sizes, i.e., 6, 8, and ten mesh using sieve shake. The third particle size is then determined its water content using gravimetric analysis method. The sample is then placed in a tray and dried in a tray dryer. The machine used is $14 \times 13 \times 1.5 \mathrm{~cm}$ with the top open. In this study drying conditions varied, i.e., drying air temperature between $60-80{ }^{\circ} \mathrm{C}$, drying air velocity $0.6-1.5 \mathrm{~m} / \mathrm{s}$ and particle size 6-10 mesh.

The drying characteristics of the experimental results are expressed in moisture content as a function of time and rate of drying as a function of free moisture. Data on drying characteristics of the experimental results were analyzed using two semiempirical models, the Two Exponential and Midilli models. Analysis of this model is done to determine the model parameters.

Satake T (2014) provides a method and an apparatus for Humidifying fertilizer grains. Imposed an improved method for dying fertilizer in which particularity for standard values of parameters such as temperature and moisture content be observed (Amini, 2013). Meas et al. investigates and explains the effects of different solar drying method and how it can affect the quality of fertilizer (Navalertpom, 2011) (Tharo, 2016) while O'shea and Melander (2013) proposed a drying apparatus for plant materials comprising an air preconditioning system for producing a processed air supply (Y Zhang, 2004).

The general diagram of the optimization process within the integration of ANN is shown in Fig. 1. The first the step is to retrieve data from a field in the form of pairing between treatments of $\mathrm{Xk}$ and the outcomes of $\mathrm{Yi}$, then the training process done with ANN to identify modeling the optimal weight to determine the effects of the physical plant (Yi). The second step is to optimize the output of Yi by the expected results by the user, e.g.

Optimization dry weight and production using algorithms ANN to give the best values and needs as treatment recommendation $(\mathrm{Xk})$. Each type of fertilizer is given six treatments with different combinations of fertilizers dose based on experience, and each dose combinations treatments is repeated 30 times, so the total amount of data in the dataset is 180 procedures.

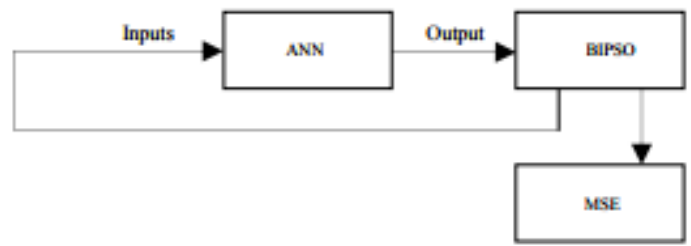

Figure 1. General Optimization Process.

Fig. 2 shows the architecture of backpropagation NN used in this research. Three steps must be done during training; the feed forward phase, the propagation phase, and phase changes in the weights [4].

PAGE NUMBER |P R O C E E D I N G $4^{\text {th }}$ I N T E R N A T I O N A L S E M I N A R : I R S T C 2017 


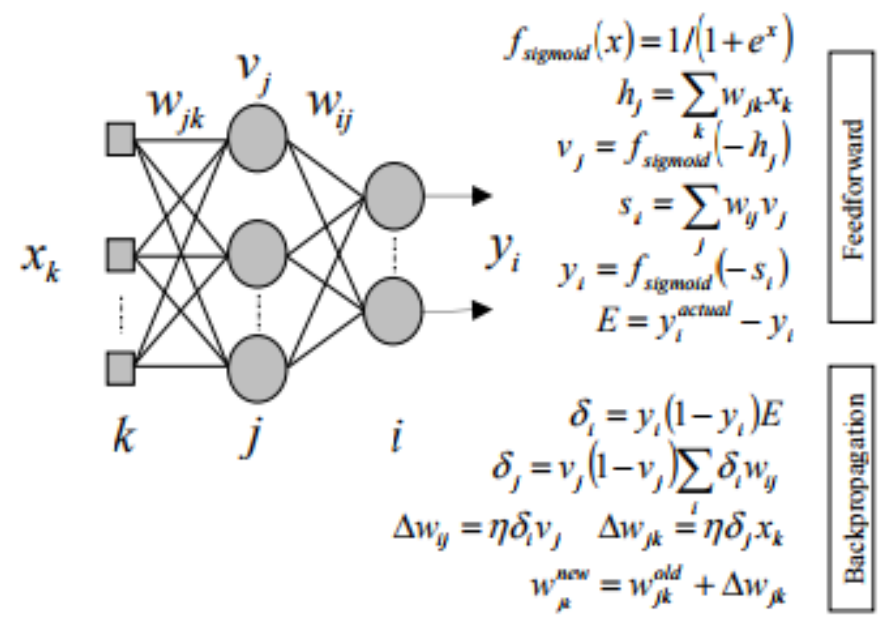

Figure 2. Architcture of ANN Methode.

Data normalization (Amini, 2013) is the process to scale the data so that the data is within a range of particular value. The method of data normalization that is used in this study is the Min-Max method (Chupungco, 2008). Where $\mathrm{x}$ is actual data, $\mathrm{x}$ ' is the result of normalization, min value is the min value of the data and max value is the max value of the data. The research conducted by Ben-Shmuel (2010), examines the effect of the stability of the concealed or hidden layer neuron in a neural network learning process. It is applied in mapping the problem of random numbers. The formula for determining the number of hidden nodes or hidden neuron is (2).

Figure 3 shows the relationship between moisture content and time. The figure indicates that the higher the dryer air temperature, the shorter the time it takes to dry the solids. Also, the increasingly upright slope of the curve shows the greater the loss of moisture caused by increasing temperature.

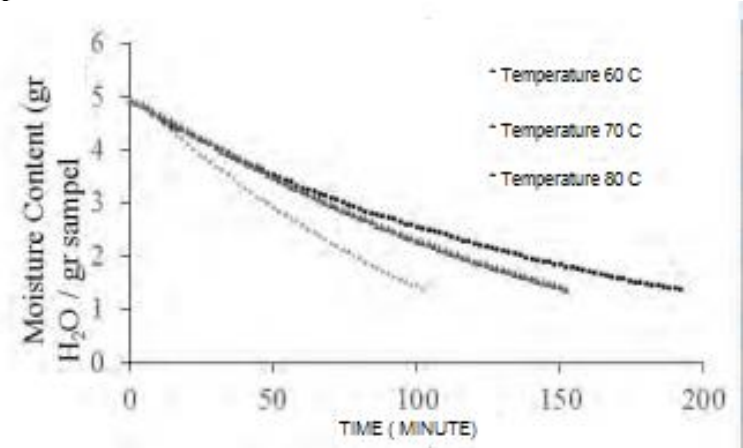

Figure 3. The Relationship Between Moisture Content And Time

\section{Design Overview}

The aims purpose of this research is to enhance a methode of the post-harvest in farming which is drying. It seeks to lessen the time to dry up fertilizer grain using sun drying as compared to a conventional drying process. It also aims to minimize intensive labor experienced by the farmers. at automatic drying machine can be arranged a map of its operation process as shown in Figure 4: 


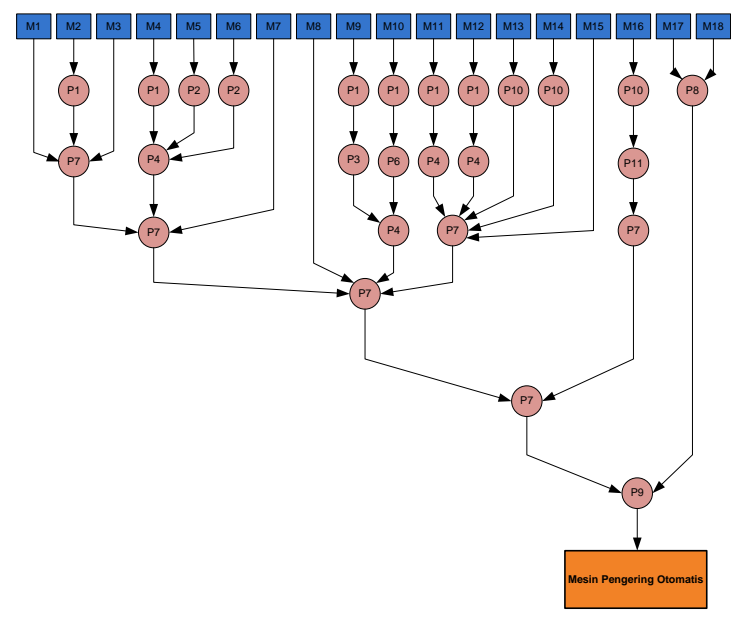

Figure 4. Maps of process the automatics machine dryer fertilizer.

A microcontroller unit operates the machine dryer fertilizer. Temperature and moisture content will be monitored so that drying will stop depending on the desired moisture content for storage. There are also heat and humid level indicators and controllers to enhance the control of drying to the intended users furthermore. SMS Notifications are also intended for updated drying status at the end of the operation. The dryer fertilizer that includes temperature and moisture content sensors to measure necessary parameters, to work simultaneously, microcontroller to act as a command unit for the tasks, solar panels to harness solar energy, batteries to store energy from the source.

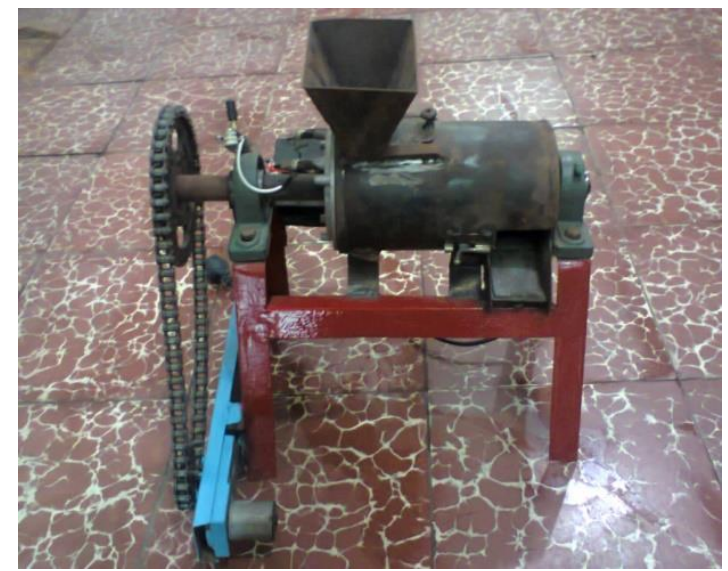

Figure 5. the prototype of machine dryer fertilizer

\section{Result and Discussion}

In this test, there are nine variations in the amount of training data and test data that are used in the training process. The number of iterations that were employed in this study was 100 iterations, the value of learning rate was $0.64,0.4$ and momentum values for a total number of a hidden layer was 4 . Testing results on the variation of training data and testing data are shown in Fig. 4. The graphics on Fig. 4 show that the different combinations of training and testing data will produce the variation on dryer fertilizer. The smallest MSE is obtained at the change of $90 \%$ training data and $10 \%$ testing data with the results value of 9.9936E-03.

The project's design originally includes solar panel As its primary power source and having the Solar Panel as its alternative. Table 1 shows the test results for the grain dryer in a 4-6 Hour duration. It utilized two sacks of fertilizer equivalent to $80 \mathrm{~kg}$. The test setup contains eight samples with $10 \mathrm{~kg}$ per sample. Due to moisture content, after drying the final weight per sample is reduced which is equivalent to the removal of moisture content. 
Table 1. Test Results for the fertilizer dryer in a 4-6 hour Duration Manual

\begin{tabular}{|c|c|c|c|c|}
\hline $\begin{array}{c}\text { Grain } \\
\text { SAMPLE }\end{array}$ & $\begin{array}{c}\text { Initial } \\
\text { Weight }\end{array}$ & $\begin{array}{c}\text { Final } \\
\text { Weight } \\
(\mathbf{k g})\end{array}$ & $\begin{array}{c}\text { EMC } \\
(\%)\end{array}$ & $\begin{array}{c}\text { MOISTURE } \\
\text { REMOVED } \\
(\%)\end{array}$ \\
\hline Sample 1 & 10 & 8.94 & 11.8 & 10.6 \\
\hline Sample 2 & 10 & 8.55 & 16.9 & 14.5 \\
\hline Sample 3 & 10 & 8.44 & 18.4 & 15.6 \\
\hline Sample 4 & 10 & 7.98 & 25.2 & 20.2 \\
\hline Sample 5 & 10 & 8.75 & 14.29 & 12.5 \\
\hline Sample 6 & 10 & 8.18 & 22.25 & 18.2 \\
\hline Sample 7 & 10 & 8.83 & 13.25 & 11.7 \\
\hline Sample 8 & 10 & 8.64 & 15.74 & 13.6 \\
\hline
\end{tabular}

Tables 2. Test Result use machine dryer fertilizer

\begin{tabular}{|c|c|c|c|c|c|c|c|c|}
\hline \multirow[t]{2}{*}{ No. } & \multirow[t]{2}{*}{ Samples } & \multirow{2}{*}{$\begin{array}{c}\text { Weight before } \\
\text { dryer } \\
(\mathrm{kg})\end{array}$} & \multicolumn{3}{|c|}{$\begin{array}{l}\text { Weight after dryer } \\
(\mathrm{kg})\end{array}$} & \multirow{2}{*}{$\begin{array}{l}\text { Average } \\
\text { weight } \\
(\mathrm{Kg})\end{array}$} & \multirow{2}{*}{$\begin{array}{l}\text { Moisture } \\
\text { weight } \\
(\mathrm{kg})\end{array}$} & \multirow{2}{*}{$\begin{array}{c}\text { Moisture } \\
\text { removed } \\
(\%)\end{array}$} \\
\hline & & & 1hours & 2hours & 3hours & & & \\
\hline 1. & Sample 1 & 100 & 112 & 115 & 110 & 112,3 & 12,3 & 10 \\
\hline 2. & Sample 2 & 200 & 228 & 231 & 234 & 231 & 31 & 12 \\
\hline 3. & Sample 3 & 300 & 340 & 338 & 342 & 340 & 40 & 11.6 \\
\hline 4. & Sample 4 & 400 & 465 & 462 & 467 & 465,6 & 65,6 & 10.3 \\
\hline 5. & Sample 5 & 500 & 582 & 585 & 579 & 582 & 82 & 20 \\
\hline
\end{tabular}

\subsection{Solar Panel Computation}

Based on the solar panel specification, the following estimates were obtained:

Number of Cells $=25$ cells

Power per Cell $=4$ watts

Voltage per cell $=.5$ Volts

Total wattage of the solar panel: $25 \times 4 \mathrm{~W}=100 \mathrm{~W}$

Total Voltage of the solar panel: $25 \times .5 \mathrm{~V}=1 \mathrm{~V}$

\subsection{Power Capacity and Consumption}

Since the 1000-W blower and motor consumes majority of the power, the following computations were obtained. With the 1000-W Blower, two alternating batteries source of energy with $100 \mathrm{~A}$-hr charging capacity at $12 \mathrm{~V}$ and a $2 \mathrm{~A}$ Wiper motor at $12 \mathrm{~V}$ :

Total System Power: 2 x $12 \mathrm{~V}=24 \mathrm{~W}+1000 \mathrm{~W}$

Battery wattage Capacity: $100 \mathrm{~A}-\mathrm{hr} \times 12 \mathrm{~V}=1200 \mathrm{~W}-\mathrm{hr}$

Battery Working time $=1200 \mathrm{~W}-\mathrm{hr} / 1000 \mathrm{~W}=1.2$ hours

With the computed values above, it should be noted that the system does not require the blower to operate continuously.

\subsection{General Observation}

During the entire machine process, the mechanical part seems to have a creaky sound in its shaft part due to its Continuous spinning during actual operation. After the fertilizer grains have been dried, due to the machine's base, there seems to be quite some difficulty in releasing the seeds from the bin that it must be tilted by several degrees to remove the remaining fertilizer grain inside. 


\section{Conclusion}

In this study, testing is done only on the parameters of ann for value dry of fertlizer. The smallest MSE value obtained is 8.6023E-03. This value is obtained by testing using training data of $90 \%, 10 \%$ test data, 100 iterations, the number of hidden layer is 10 , learning rate of 0.6 and momentum is 0.6 . The proposed method can complete the drying process faster compared to the traditional way of drying. A single humidity sensor controls the moisture content and the temperature inside the drying chamber. And a fertilizer Dryer significantly reduces the labor of the farmers regarding drying due to its efficiency.

\section{Acknowledgment}

I would like thank to Universitas Pembangunan Panca Budi Medan to support our research.

\section{References}

Amini, Mohsen and Majid Bazargan. (2013). Two Objective Optimization in Shell-and-Tube Heat Exchangers using Genetic Algorithm. Department of Mechanical Engineering, K. N. Toosi University of Technology, 15 Pardis St., Mollasadra St., Tehran 1999143344, Iran.

Ben-Shmuel, E., Atzmony, D., Shaham, G., Bilchinsky, A. (2013). Drying Apparatus and Methods and Accessories for use therewith. Pub. No. US2010/0115785 A1

Ben-Shmuel, E., Atzmony, D., Shaham, G., Bilchinsky, A. (2013). Drying Apparatus and Methods and Accessories for use therewith. Pub. No. US2010/0115785 A1

Chupungco, J., Dumayas, E., Mullen, J. ( 2008 ) Two Stage drying in the Philippines ACIAR Impact Assessment Series Report No. $59,50 \mathrm{pp}$

D. Bratton, J. Kennedy, (2012). Defining a standard for particle swarm optimization, IEEE SwarmIntelligence Symposium, SIS'2007, 2007 Apr. 1-5, Honolulu, Hawaii, New Jersey, pp. 120-127.

HL Chen, at all. (2012), An Adaptive Fuzzy K-Nearest Neighbor Method Based on Parallel Particle Swarm Optimation for Bankruptcy Prediction, Part 1 LNAI 6634 Page 249-264, Springer-Verlag Berlin Heidelberg.

Mirza Cilimkovic, Neural Networks and Back Propagation Algorithm. Institute of Technology Blanchardstown, Blanchardstown Road North Dublin 15, Ireland.

Navalertporn, Thitipong, and Afzulpurkar, Nitin. (2011). Optimization Of Tile Manufacturing Process Using Particle Swarm Optimization. Industrial System Engineering, School of Engineering and Technology, Asian Institute of Technology. Thailand.

O'shea, T. (2013). Scalable Pilot Dryer. Pub. No. WO 2013/082082 A1

Ondier, G. O., Siebenmorgen, T. J., Mauromoustakos, A. (2010). Low-temperature, low-relative humidity drying of rough rice. Journal of Food Engineering

Satake, T. (2014). Method for Humidifying Rice Grains. Pub. No. US5002788

Tharo, Z., \& Siahaan, A. P. (2016). Improvisation Analysis of Reactive Power Energy Saving Lamps Based on Inverter. International Journal of Engineering and Techniques, 141-145.

Y, Zhang., S, Huang. 2004. A Novel Multiobjective Particle Swarm Optimization for Buoy-arrangement Design. Shenyang Institute of Automation the Graduate School of Chinese Academy of Science. Senyang, China.

Zou, Jifeng, Chenlong Li, and Qiao Li, 2015. Fault Prediction Method based on SVR of Improved PSO. School of Information Science and Engineering, Shenyang Ligong University, Shenyang 110159, China 